\title{
MADRIGAIS DE INICIAÇÃO
}

\section{Primeiro Movimento}

Isadora Machado ${ }^{1}$

\section{I}

Tomas de pesar o amuleto. Esfinge e vício prossegue na Falta. Lenta breve lamuria as sete montanhas do Paraíso desejado pelo Gozo. Persegue o que aprendiz e Faz-te grande e pedregoso nesse imenso inferno. Adia. Dói o vermelho que te come a pele e faz do sangue essa Carne ossosa de sabor. Fatigado do luto, despede-te:

- tudo mais é tardança.

Saio em busca d'um apesar, E'ntorno-me em curso. Rio. Ser pedra me move margem: Adiante penso mar. Entregue, Oriento a seita, floema de fora. Estar terra me guia fim,

Volteia em mim a coragem da planta.

III

Cantos de peixe não me cabem:

Pó de seixo pra perder a trilha.

Danceia a Vontade, é sina. Fluido

fluxo, poema da fleuma.

Harpeia meu solo estandarte:

é arte, é arte! Antecipo a memória.

Reina, pois, em mim, a intermitência da Pedra.

IV

Fatia de tempo fora do fluxo

Feita de falta, a mariposa flui.

Mas mareada por todas as ausências que me

Navegam,

Habito em cada encontro que procuro, e

Como a cura dos desejos, obscuros meus.

Sem saber o que ver, abri os ouvidos ao

Infinito

De um Velho Diabo:

Devora-me se te decifro, 
Causa impossivel da vida!

Passeia em mim a inquietude das areias

Dele, levo as cores pintadas nos olhos. Mistérios.

Meus. Dança em meus poros-olhos, cuidate mucho.

Saiba ser o balé das calles fartas de ida. Espaça.

E não demore. Venha a mim, Pirata.

Que em tua espalda caminharão meus medos tesos.

Promessas d'a despeito....Peregrinar imenso. Verso

É essa sua língua procurando meu cheiro.

Hábraços. Castos pela ida que já vinha, teci, teceram.

Miro as estrelas e é incerto o teu instante. Promessa

De um dia Ser essa tua guia. Usa-me de castiçal

Para teus poemas llenos de dolor. Acusa-me.

Farta da escusa busca, dá-me tus dedos.

- ¡Ensinar-te-ei los caminos de mi Flauta!

Verás a chuva e o Pé de Manga e fazer-lhe-te-á cócegas a minha retina tenra. Tomar-me-á pelo braço, e me dirá coisas exatas ao paladar da orelha. Estranho pecado olvidar. Pétala:

cai, seca. Sexo na sarjeta é nome de prosseguir. E que firme síntese esta a do desejo. Admiro-o.

Acossada.

\section{VII}

Carrego as pupilas dilatadas por esse amor que não foi. E a falta da ausência, do tempo, das tardes. De tudo que não pôde ser. Por que, Deus-do-Tempo? Por quê?

Porque fez de mim essa memória. De não poderes me fez chegar ao limbo que Te consome aos poucos. E se hoje prenha e bela, espera, pois de mim não farás castiçal de lembranças.

\section{VIII}

No esgotamento das forças é que se dá a ver o homem. $\mathrm{Na}$ dor que treme, seus olhos marejados pela entrega

Não quer mais Ser o cansaço que o espera. Na vida, - razão nômade, o Corpo

Se faz templo sagrado da Busca. Suspeita

No peito, a maldição. 
- em que palavra me enganaram teus óculos?

Que, Velho Diabo, venha: Salga

Meu mamilo esquerdo com o mar,

Este que navega sem bússola por tua língua.

Dá-me teu Verbo arrebentado

Que dele faço meu falo,

Dele, minha fala:

- Que dele faço também minha Falta.

\section{IX}

Sabia que depois de fome farta, viria

descaminho e solitude que é o gozo.

Sentir-te longe de mim. Além das milhas,

longe também as preces. Mas nos achega o mar.

Imagino a ti como sei o sal cor-

roendo a água que resta na pele. Tal como

tu fizestes, noite úmida, com meu pesar.

O que pode a Bruxa contra o Diabo?

Pode ainda ser mulher, e reinventar-se

sangrando o passárido no próximo mês.

Meu útero vazio coagula sua ausência.

De Palavra, verbo teso, tu preencheste

Esse corpo assintático com teu patoá.

Mas a homília mundana esvazia o ventre desta

Que é Mariposa, e tão tarde Mulher, e em riste

Poeta.

No te apures...

Sangrarei minhas chagas pelo mesmo labirinto

Pelo qual adentraste e descobriste o mundo.

Redesenharei caminhos. Sabotarei os mapas.

Meteste na primeira fresta entreaberta, e errou.

Acertaste minha garganta, cordas desta nau.

Ateaste vida no silêncio errado. Pois ele, Febre conspurcada,

Habitava entre minhas pernas. E que fizeste entre elas?

Fecundaste meu Verbo, mas não, nada,

Não logrou silenciá-lo. 
Aislada, prosseguirei no vício. Cuidate mucho, que o embrião morto cuidará das notícias sanguíneas.

\footnotetext{
1 Isadora Machado é Doutoranda em Linguística no Instituto de Estudos da Linguagem (Fapesp/Unicamp). Estes poemas são o primeiro capítulo de um livro em processo que se intitula Misantrópolis. E-mail: ultimaflordolacio@g mail.com
} 